\title{
Nutritional aspects of corn due to cover crops, nitrogen doses and inoculation with Azospirillum brasilense
}

\author{
José Roberto Portugal ${ }^{1 *}$, Orivaldo Arf $^{1}$, Amanda Ribeiro Peres ${ }^{2}$, Flávia Constantino Meirelles ${ }^{1}$, Ricardo \\ Antônio Ferreira Rodrigues ${ }^{2}$, Alex Rangel Gonzaga ${ }^{1}$, Nayara Fernanda Siviero Garcia ${ }^{1}$, Daiene Camila Dias \\ Chaves Corsini $^{1}$
}

\author{
${ }^{1}$ São Paulo State University (UNESP), Department of Plant Science, Food Technology and Social Economy, Ilha \\ Solteira, State of São Paulo, Brazil \\ ${ }^{2}$ São Paulo State University (UNESP), Department of Plant Health, Rural Engineering and Soil, Ilha Solteira, State of \\ São Paulo, Brazil
}

\section{*Corresponding author: jrp.agrunesp@gmail.com}

\begin{abstract}
In modern agriculture, there is a challenge for adequately nourishing plants using sustainable techniques, mitigating the use of mineral fertilizers, especially nitrogenous fertilizers, which are the most used for corn crops. The objective of this study is to evaluate the accumulation potential of nitrogen, phosphorus and potassium in: a) cover crops (millet, crotalaria, pigeon pea, millet + crotalaria, millet + pigeon pea and fallow) and b) corn plants sown in succession to the cover crops and with application of nitrogen doses $\left(0,40,80\right.$ and $\left.120 \mathrm{~kg} \mathrm{ha}^{-1}\right)$ in topdressing and inoculation via seeds using Azospirillum brasilense. The experiment comprised randomized blocks in a $6 \times 4 \times 2$ factorial design totaling 48 treatments and 4 replications. The study was conducted at the Experimental Farm of the Faculty of Engineering (UNESP), Ilha Solteira campus, located in the municipality of Selvíria, Mato Grosso do Sul (MS) state. The soil of the site is a typical clayey dystrophic Red Latosol. The millet + crotalaria intercropping allows the accumulation of high amounts of $\mathrm{N}$ and $\mathrm{K}$ and results in a great accumulation of dry matter and nutrients in corn plants sown in succession. Application of nitrogen in topdressing provided an increase in the accumulated dry matter of corn plants of up to $85 \mathrm{~kg}$ $\mathrm{ha}^{-1}$. Inoculation via seeds using Azospirillum brasilense did not increase the accumulation of dry matter and nutrients of corn plants. It is recommended to cultivate corn in succession to the millet + crotalaria and the aplication of 80 to $100 \mathrm{~kg} \mathrm{ha}^{-1}$ of $\mathrm{N}$ in topdressing aiming at better nutrition of the plants.
\end{abstract}

Keywords: Zea Mays L.; plant nutrition; green manure; nitrogen; diazotrophic bacteria.

Abbreviations: a.i._ active ingrediente; Ca_calcium; $\mathrm{DAE}_{\text {_ days }}$ after emergence; K_potassium; $\mathrm{K}_{2} \mathrm{O} \_$potassium oxide; Mg_magnesium; N_nitrogen; P_phosphorus; S_sulfur; $\mathrm{P}_{2} \mathrm{O}_{5}$ _phosphorus pentoxide; PGPB_plant growth-promoting bacteria; PRNT_ relative power of total neutralization

\section{Introduction}

In areas cultivated with corn crops, the most important aspect is plant nutrition. It aims to nourish the plant adequately, minimizing losses and making the use of nutrients more efficient, especially nitrogen $(N)$, phosphorus (P) and potassium (K), which are the most extracted nutrients from the soil by corn plants. According to Coelho and França (1995) and Von Pinho et al. (2009), corn plants accumulate macronutrients in shoot dry matter in the following decreasing order: N $>\mathrm{K}>\mathrm{P}>\mathrm{Ca}>\mathrm{Mg}>\mathrm{S}$. Given the high economic and environmental costs of the mineral fertilizer manufacturing process, agriculture faces the challenge of increasing crop production and reducing the use of fertilizers to make the agricultural system sustainable (Marini et al., 2015). In this context, it is necessary to seek other forms of supplying nutrients for crops, especially corn.

In general, green manure or cover crops, used for the formation of straw for the direct seeding system, play a fundamental role in the cycling of nutrients, both from mineral fertilizers and not used by commercial crops and from the mineralization of soil organic matter (Torres et al., 2008). This allows the production of food using a low amount of mineral fertilizer (Buzinaro et al., 2009), consequently reducing production costs (Ferreira et al., 2012). According to Silva et al. (2006), in an average of two years, nutrient accumulation in crotalaria plants occur in the following decreasing order: $\mathrm{K}>\mathrm{N}>\mathrm{P}\left(230,180\right.$ and $28 \mathrm{~kg} \mathrm{ha}^{-1}$, respectively). In millet plants, nutrient accumulation is $\mathrm{K}>\mathrm{N}>\mathrm{P}\left(182,66\right.$ and $19 \mathrm{~kg} \mathrm{ha}^{-1}$, respectively). Gitti et al. (2012) reported the accumulation of $54 \mathrm{~kg} \mathrm{ha}^{-1}$ of $\mathrm{K}, 44 \mathrm{~kg}$ $\mathrm{ha}^{-1}$ of $\mathrm{N}$ and $8 \mathrm{~kg} \mathrm{ha}^{-1}$ of $\mathrm{P}$ in pigeon pea plants, $125 \mathrm{~kg} \mathrm{ha}^{-1}$ of $\mathrm{K}, 75 \mathrm{~kg} \mathrm{ha}^{-1}$ of $\mathrm{N}$ and $16 \mathrm{~kg} \mathrm{ha}^{-1}$ of $\mathrm{P}$ in millet + crotalaria plants, and $80 \mathrm{~kg} \mathrm{ha}^{-1}$ of $\mathrm{K}, 56 \mathrm{~kg} \mathrm{ha}^{-1}$ of $\mathrm{N}$ and $12 \mathrm{~kg} \mathrm{ha}^{-1}$ of $\mathrm{P}$ 
in millet + pigeon pea plants. That is, plant cover species have a potential to supply nutrients to corn crops, mainly $\mathrm{N}$, $\mathrm{P}$ and $\mathrm{K}$, which are the most required nutrients by this crop. For corn, the most important nutrient is nitrogen. It limits production the most (Fornasieri Filho, 2007; Roberto et al., 2010; Silva et al., 2013) and is the costliest element for production (Amado et al., 2002). Usually, corn crops require nitrogen fertilization in topdressing to complement the amount of nutrients supplied by the soil (Nunes et al., 2013). The efficiency of nitrogen absorption by plants is usually equal to or less than $60 \%$ (Broch and Ranno, 2008). In order to increase the efficiency of nitrogen fertilization, it is important to take into account the soil nitrogen dynamics since it is a nutrient subjected to leaching losses, ammoniacal volatilization $\left(\mathrm{N}-\mathrm{NH}_{3}\right)$, immobilization, mobilization, nitrification, denitrification and mineralization (Rambo et al., 2004). Another important factor to improve the efficiency of nitrogen fertilization is to know the history of the area, that is, depending on the crops preceding the corn crop in a same area, it is possible to better manage nitrogen doses, sources and application.

Plant Growth-Promoting Bacteria (PGPB) are able to fix atmospheric nitrogen, solubilize phosphorus and iron, and produce plant hormones such as auxins, gibberellins, cytokinins and ethylene (Bashan and Bashan, 2005). Plants of the genus Azospirillum, when inoculated, may not reach an efficiency similar to that of rhizobia-leguminous symbioses in the soil. However, the contribution of $\mathrm{N}$ fixed by grasses is approximately $25-50 \mathrm{~kg} \mathrm{~N} \mathrm{ha}^{-1}$ year $^{-1}$, equivalent to the average $N$ supply of approximately $17 \%$ of the crop demand (Moreira et al., 2010). According to Hungria et al. (2010), there should be an increase in the use of inoculants in the coming years due to increased fertilizer costs, pollution concerns and a focus on sustainable agriculture. This increase should help to achieve the objective of reducing the use of chemical fertilizers. Factors that interfere with crop responses to inoculation of Azospirillum are not yet fully understood (Repke et al., 2013). Therefore, the results are still inconsistent and further studies aiming to improve inoculation efficiency are required.

Thus, studies aimed at reducing or optimizing the use of fertilizers are important, such as the use of different species of cover crops and plant growth promoting bacteria that can contribute to better nutrition of corn plants and nutrient cycling making the production system more sustainable.

The objective of this study is to evaluate the accumulation potential of nitrogen, phosphorus and potassium of cover crops (millet, crotalaria, pigeon pea, millet + crotalaria, millet + pigeon pea and fallow) and corn plants sown in succession to this cover crops in function of nitrogen doses $\left(0,40,80\right.$ and $\left.120 \mathrm{~kg} \mathrm{ha}^{-1}\right)$ and inoculation via seeds using Azospirillum brasilense.

\section{Results and discussion}

\section{Climatic aspects}

The accumulation of rainfalls during the crop cover cycle in the first and the second cropping years (Fig $1 \mathrm{~A}$ and $\mathrm{B}$ ) was $182 \mathrm{~mm}$ and $228 \mathrm{~mm}$, respectively. In addition to a low volume of rainfalls during the first year, there was an irregular rainfall distribution and high temperatures during the full vegetative development stage. Such drought periods were managed by sprinkler irrigation.

For corn crops, the cumulative rainfalls until flowering was, during the first agricultural year $(174 \mathrm{~mm})$, approximately $3.6 \mathrm{~mm} /$ day; for the second year $(271 \mathrm{~mm})$, approximately $5.5 \mathrm{~mm} /$ day (Fig $1 \mathrm{~A}$ and $\mathrm{B}$ ). It is noteworthy that there was water supplementation by irrigation. According to Fornasieri Filho (2007) and Fancelli (2015), corn crops require $400-600 \mathrm{~mm}$ of rainfall to produce normally without the need for irrigation. Fancelli (2015) pointed out that water consumption by the crop, in hot and dry weather, rarely exceeds $3.0 \mathrm{~mm} \mathrm{day}^{-1}$ as long as the plant has 7-8 leaves. However, between earing and maturation, this water consumption may increase to $5.0-7.5 \mathrm{~mm}$ per day. The author reports that $4.5 \mathrm{~mm} /$ day should be considered the average water consumption by corn independent from the phenological phase.

\section{Accumulation of $N, P$ and $K$ in cover crops}

According to the average $\mathrm{N}$ values accumulated during the first year (Table 1), high $N$ values were observed for crotalaria and millet + crotalaria, differing from millet and pigeon pea. Silva et al. (2006), Ohland et al. (2005) and Kappes (2011) reported that crotalaria, in addition to a high dry matter production, is associated with rhizobia that fixate atmospheric $\mathrm{N}_{2}$, resulting in a high $\mathrm{N}$ content in the dry matter. Silva et al. (2006) reported that crotalaria provides an accumulated amount of $\mathrm{N}$ approximately 2.7 and 5.8 times higher than millet and fallow, respectively. Torres et al. (2005) observed a high accumulated $\mathrm{N}$ in crotalaria in relation to millet, but it did not differ from pigeon pea.

During the second agricultural year, vegetation cover comprising millet + crotalaria resulted in a higher amount of accumulated N compared to fallow. Gitti et al. (2012) reported amounts of $\mathrm{N}$ accumulated in crotalaria and millet + crotalaria of 75.5 and $74.9 \mathrm{~kg} \mathrm{ha}^{-1}$, respectively. Such treatments were superior to pigeon pea $\left(44.4 \mathrm{~kg} \mathrm{ha}^{-1}\right)$. Teixeira et al. (2009) observed a high accumulation of $\mathrm{N}$ in the millet + crotalaria treatment $\left(252.11 \mathrm{~kg} \mathrm{ha}^{-1}\right)$ compared to the millet treatment $\left(131.10 \mathrm{~kg} \mathrm{ha}^{-1}\right)$. Perin et al. (2004) reported a higher value for accumulated $\mathrm{N}$ in the millet + crotalaria intercropping compared to a spontaneous vegetation treatment.

As for the amount of $P$ accumulated during the first agricultural year (Table 1), the crotalaria treatment resulted in values higher than the pigeon pea treatment. This was due to its slow growth and low dry matter accumulation during the experimental period. Pigeon pea plants have a high nutrient content until the flowering phase, but little accumulation of dry matter. As the cover crops was managed 63 days after emergence (DAE), during the flowering period of crotalaria and millet, the pigeon pea, because of its slower growth, presented a low accumulation of dry matter. This resulted in the lowest content of nutrient per area.

Kappes et al. (2013b) also observed a high amount of $P$ in crotalaria plants. Similarly, Gitti et al. (2012) observed a higher $\mathrm{P}$ content for crotalaria and millet + crotalaria than for pigeon pea. Torres et al. (2008), obtaining a total dry matter of $3,900 \mathrm{~kg} \mathrm{ha}^{-1}$ for crotalaria and $1,600 \mathrm{~kg} \mathrm{ha}^{-1}$ for pigeon pea, reported a $\mathrm{P}$ accumulation of 10.80 and $5.20 \mathrm{~kg}$ $\mathrm{ha}^{-1}$ for crotalaria and pigeon pea, respectively. During the 
Table 1. Average values of accumulated nitrogen $\left(\mathrm{N}_{\mathrm{A}}\right)$, accumulated phosphorus $\left(\mathrm{P}_{\mathrm{A}}\right)$ e accumulated potassium $\left(\mathrm{K}_{\mathrm{A}}\right)$ in different cover crops, preceding the corn cultivation. Selvíria - MS, Brazil (Harvest 2012/13 and 2013/14).

\begin{tabular}{|c|c|c|c|c|c|c|}
\hline \multirow{3}{*}{ Cover crops } & \multicolumn{2}{|c|}{ NA } & \multicolumn{2}{|c|}{ PA } & \multicolumn{2}{|c|}{ KA } \\
\hline & \multicolumn{6}{|c|}{ 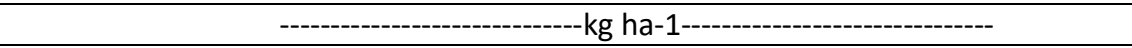 } \\
\hline & $12 / 13$ & $13 / 14$ & $12 / 13$ & $13 / 14$ & $12 / 13$ & $13 / 14$ \\
\hline Crotalaria & $123.82 \mathrm{a}$ & $109.01 \mathrm{ab}$ & $17.50 \mathrm{a}$ & 14.19 & $123.93 \mathrm{ab}$ & $83.29 \mathrm{ab}$ \\
\hline Pigeon pea & $81.89 \mathrm{~b}$ & $93.52 \mathrm{ab}$ & $13.68 \mathrm{~b}$ & 12.05 & $104.15 \mathrm{~b}$ & $61.52 \mathrm{~b}$ \\
\hline Millet & $85.27 \mathrm{~b}$ & $72.31 \mathrm{ab}$ & $14.54 a b$ & 10.28 & $146.27 \mathrm{ab}$ & $94.37 \mathrm{ab}$ \\
\hline Millet + Crotalaria & $121.00 \mathrm{a}$ & $110.51 \mathrm{a}$ & $17.12 \mathrm{ab}$ & 14.82 & $159.55 \mathrm{a}$ & $109.57 \mathrm{a}$ \\
\hline Millet + Pigeon pea & $108.21 \mathrm{ab}$ & $75.09 a b$ & $15.58 \mathrm{ab}$ & 12.69 & $132.64 a b$ & $98.02 a b$ \\
\hline Fallow & $97.55 a b$ & $71.37 b$ & $14.02 \mathrm{ab}$ & 12.40 & $150.76 \mathrm{ab}$ & $81.60 \mathrm{ab}$ \\
\hline LSD & 35.24 & 38.41 & 3.49 & - & 53.20 & 37.53 \\
\hline $\mathrm{F}$ test(1) & $5.356 * *$ & $4.77^{* *}$ & $4.842 * *$ & $1.329 \mathrm{~ns}$ & $3.059 *$ & $4.14^{* *}$ \\
\hline CV (\%) & 14.90 & 18.86 & 9.77 & 22.03 & 17.00 & 18.49 \\
\hline Average & 102.96 & 88.63 & 15.55 & 12.74 & 136.21 & 88.06 \\
\hline
\end{tabular}

(1) ns, ** and * - not significant, significant at $1 \%$ and $5 \%$ probability, respectively; Means followed by the same letter in the columns do not differ by Tukey test at $5 \%$ probability; LSD - least significant difference by Tukey test; CV - coefficient of variation.

Table 2. Average values of initial population (PIP) and accumulated shoot dry matter (SDM) of corn plants, in function of inoculation with Azospirillum brasilense, cover crops and doses of N in topdressing. Selvíria - MS, Brasil (Harvest 2012/13 and 2013/14).

\begin{tabular}{|c|c|c|c|c|c|}
\hline \multirow{3}{*}{ Trataments } & \multirow{2}{*}{\multicolumn{3}{|c|}{$\begin{array}{l}\text { PIP } \\
\text { plants ha-1 }\end{array}$}} & \multirow{2}{*}{\multicolumn{2}{|c|}{$\frac{\text { SDM }}{\text { kg ha-1 }}$}} \\
\hline & & & & & \\
\hline & & $12 / 13$ & $13 / 14$ & $12 / 13$ & $13 / 14$ \\
\hline \multicolumn{6}{|l|}{ Inoculation (I) } \\
\hline With & & 55,870 & 65,027 & 5,789 & 5,597 \\
\hline Without & & 57,008 & 65,104 & 5,843 & 5,753 \\
\hline LSD & & - & - & - & - \\
\hline \multicolumn{6}{|l|}{ Cover crops (C) } \\
\hline Crotalaria & & $56,424 a b$ & 64,583 & 5,798 & $5,985 \mathrm{a}$ \\
\hline Pigeon pea & & $59,198 \mathrm{a}$ & 64,930 & 6,044 & $5,594 a b$ \\
\hline Millet & & $54,958 \mathrm{~b}$ & 65,104 & 5,712 & $5,529 a b$ \\
\hline Millet + Crotalaria & & $56,151 a b$ & 64,757 & 5,705 & $5,930 \mathrm{a}$ \\
\hline Millet + Pigeon pea & & $55,748 b$ & 65,220 & 5,840 & $5,207 b$ \\
\hline Fallow & & $56,154 a b$ & 65,799 & 5,798 & $5,806 a b$ \\
\hline LSD & & 3,312 & - & - & 676.12 \\
\hline \multicolumn{6}{|l|}{ Doses of $N(D)$} \\
\hline 0 kg ha-1 & & - & - & 5,896 & 5,212 \\
\hline $40 \mathrm{~kg}$ ha-1 & & - & - & 5,637 & 5,677 \\
\hline 80 kg ha-1 & & - & - & 5,912 & 6,008 \\
\hline $120 \mathrm{~kg}$ ha- 1 & & - & - & 5,820 & 5,805 \\
\hline \multirow{6}{*}{$F$ test(1) } & I & $3.24 \mathrm{~ns}$ & $0.01 \mathrm{~ns}$ & $0.21 \mathrm{~ns}$ & $1.34 \mathrm{~ns}$ \\
\hline & $\mathrm{C}$ & $3.49 *$ & $0.21 \mathrm{~ns}$ & $0.72 \mathrm{~ns}$ & $3.11^{* *}$ \\
\hline & $\mathrm{D}$ & - & - & $1.12 \mathrm{~ns}$ & $6.25^{* *}$ \\
\hline & $I^{*} \mathrm{C}$ & $1.77 \mathrm{~ns}$ & $1.60 \mathrm{~ns}$ & $0.64 n s$ & $0.97 \mathrm{~ns}$ \\
\hline & $I^{*} D$ & - & - & $0.28 \mathrm{~ns}$ & $0.77 \mathrm{~ns}$ \\
\hline & $C * D$ & - & - & $1.40 \mathrm{~ns}$ & $0.87 \mathrm{~ns}$ \\
\hline CV (\%) & & 3.88 & 4.06 & 14.2 & 16.49 \\
\hline Average & & 56,439 & 65,066 & 5,816 & 5,675 \\
\hline
\end{tabular}



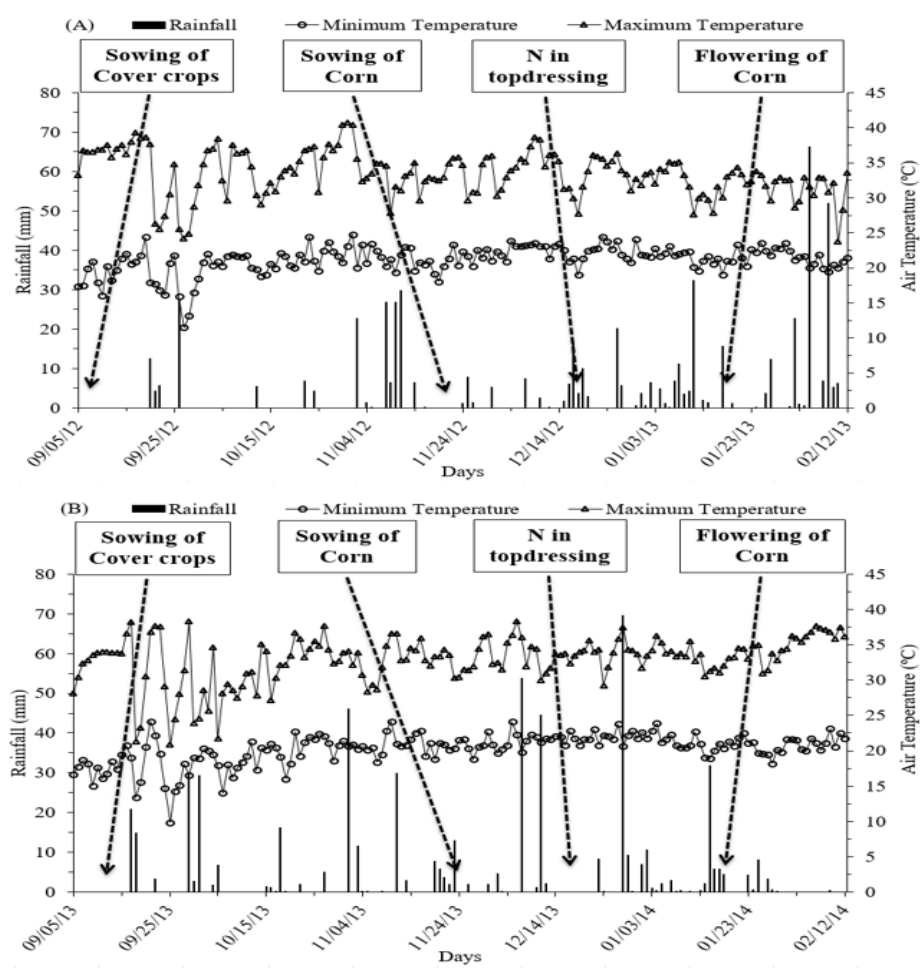

Fig 1. Rainfall daily data and air minimum and maximum temperature during the experimental period. Selvíria - MS, Brazil (Harvest 2012/13 (A) and 2013/14 (B))

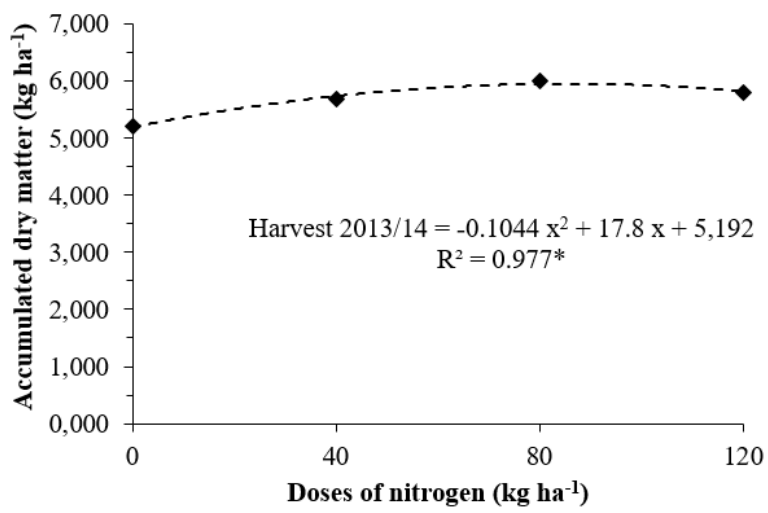

Fig 2. Accumulated dry matter of corn plants, in function of nitrogen doses in topdressing. Selvíria - MS, Brazil (2013/14). F test: * significant at $5 \%$ probability.

Table 3. Average values of accumulated amount of nitrogen $\left(\mathrm{N}_{A}\right)$, phosphorus $\left(\mathrm{P}_{A}\right)$ and potassium $\left(\mathrm{K}_{A}\right)$ in the dry matter of corn plants, in function of inoculation with Azospirillum brasilense, cover crops and doses of $\mathrm{N}$ in topdressing. Selvíria - MS, Brasil (Harvest 2012/13 and 2013/14).

\begin{tabular}{|c|c|c|c|c|c|c|}
\hline \multirow{3}{*}{ Trataments } & \multicolumn{2}{|c|}{ NA } & $P$ & & \multicolumn{2}{|c|}{ KA } \\
\hline & \multicolumn{6}{|c|}{ 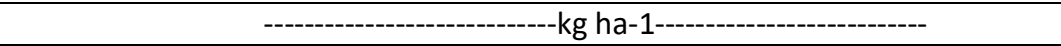 } \\
\hline & $12 / 13$ & $13 / 14$ & $12 / 13$ & $13 / 14$ & $12 / 13$ & $13 / 14$ \\
\hline \multicolumn{7}{|c|}{ Inoculation (I) } \\
\hline With & 103.6 & 78.94 & 18.8 & 12.8 & 139.4 & 116.9 \\
\hline Without & 103.0 & 80.49 & 18.6 & 13.3 & 139.4 & 118.7 \\
\hline LSD & - & - & - & - & - & - \\
\hline \multicolumn{7}{|c|}{ Cover crops (C) } \\
\hline Crotalaria & 107.3 & $87.3 \mathrm{a}$ & 17.8 & $13.4 \mathrm{ab}$ & 130.3 & $120.4 a b$ \\
\hline Pigeon pea & 103.3 & $78.4 \mathrm{ab}$ & 18.8 & $12.7 \mathrm{ab}$ & 137.2 & $115.6 \mathrm{ab}$ \\
\hline Millet & 97.8 & $74.2 \mathrm{ab}$ & 19.0 & $12.6 \mathrm{ab}$ & 136.0 & $115.4 a b$ \\
\hline
\end{tabular}




\begin{tabular}{|c|c|c|c|c|c|c|c|}
\hline Millet + Crotalaria & & 106.9 & $84.2 \mathrm{ab}$ & 19.5 & $14.5 \mathrm{a}$ & 141.5 & $125.0 \mathrm{a}$ \\
\hline Millet + Pigeon pea & & 106.3 & $72.4 \mathrm{~b}$ & 18.4 & $11.5 \mathrm{~b}$ & 148.2 & 107.4 b \\
\hline Fallow & & 98.4 & $81.8 \mathrm{ab}$ & 18.8 & $13.8 \mathrm{ab}$ & 143.1 & $123.0 \mathrm{ab}$ \\
\hline LSD & & - & 14.1 & - & 2.5 & - & 16.5 \\
\hline \multicolumn{8}{|l|}{ Doses of $N(D)$} \\
\hline 0 kg ha-1 & & 99.2 & 65.2 & 18.8 & 12.9 & 138.8 & 108.8 \\
\hline 40 kg ha-1 & & 98.4 & 79.2 & 18.2 & 13.0 & 135.9 & 121.1 \\
\hline 80 kg ha-1 & & 110.1 & 87.0 & 20.1 & 13.5 & 141.1 & 124.6 \\
\hline 120 kg ha-1 & & 105.6 & 87.4 & 17.8 & 13.0 & 141.7 & 116.8 \\
\hline \multirow{6}{*}{$\mathrm{F}$ test(1) } & I & $0.05 n s$ & $0.31 \mathrm{~ns}$ & $0.08 n s$ & $0.93 n s$ & $0.00 n s$ & $0.29 \mathrm{~ns}$ \\
\hline & $\mathrm{C}$ & $1.46 \mathrm{~ns}$ & $2.83^{*}$ & $0.42 \mathrm{~ns}$ & $2.77^{*}$ & $1.53 \mathrm{~ns}$ & $2.53^{*}$ \\
\hline & $\mathrm{D}$ & $3.64 * *$ & $13.66 * *$ & $2.07 \mathrm{~ns}$ & $0.30 \mathrm{~ns}$ & $0.41 \mathrm{~ns}$ & $4.27 * *$ \\
\hline & $I^{*} \mathrm{C}$ & $0.41 \mathrm{~ns}$ & $0.44 n s$ & $0.14 \mathrm{~ns}$ & $0.83 \mathrm{~ns}$ & $0.47 n s$ & $0.80 \mathrm{~ns}$ \\
\hline & $I^{*} \mathrm{D}$ & $0.97 \mathrm{~ns}$ & $0.91 \mathrm{~ns}$ & $2.39 \mathrm{~ns}$ & $0.70 \mathrm{~ns}$ & $0.98 \mathrm{~ns}$ & $0.26 \mathrm{~ns}$ \\
\hline & $C * D$ & $1.12 \mathrm{~ns}$ & $0.74 n s$ & $0.83 n s$ & $1.06 \mathrm{~ns}$ & $1.18 \mathrm{~ns}$ & $0.41 \mathrm{~ns}$ \\
\hline CV (\%) & & 19.48 & 24.41 & 25.21 & 26.70 & 20.46 & 19.33 \\
\hline Average & & 103.3 & 79.7 & 18.7 & 13.1 & 139.4 & 117.8 \\
\hline
\end{tabular}

Table 4. Chemical analysis of the soil from the experimental area at the layer 0.00-0.20 m. Selvíria - MS, Brazil (Harvest 2012/13 and 2013/14).

\begin{tabular}{lllllllllll}
\hline Year & $\begin{array}{l}\text { P resin } \\
\mathrm{mg} \mathrm{dm}^{-3}\end{array}$ & $\begin{array}{l}\mathrm{OM} \\
\mathrm{g} \mathrm{dm}^{-3}\end{array}$ & $\begin{array}{l}\mathrm{pH} \\
\mathrm{CaCl}_{2}\end{array}$ & $\mathrm{~K}$ & $\mathrm{Ca}$ & $\mathrm{Mg}$ & $\mathrm{H}+\mathrm{Al}$ & $\mathrm{Al}$ & $\mathrm{CEC}$ & $\begin{array}{l}\mathrm{V} \\
(\%)\end{array}$ \\
\hline $2012 / 13$ & 34 & 23 & 5.0 & 2.9 & 24 & 17 & 36 & 1 & 80.4 & 55 \\
$2013 / 14$ & 32 & 22 & 5.1 & 1.4 & 25 & 17 & 42 & 1 & 85.4 & 51 \\
\hline
\end{tabular}

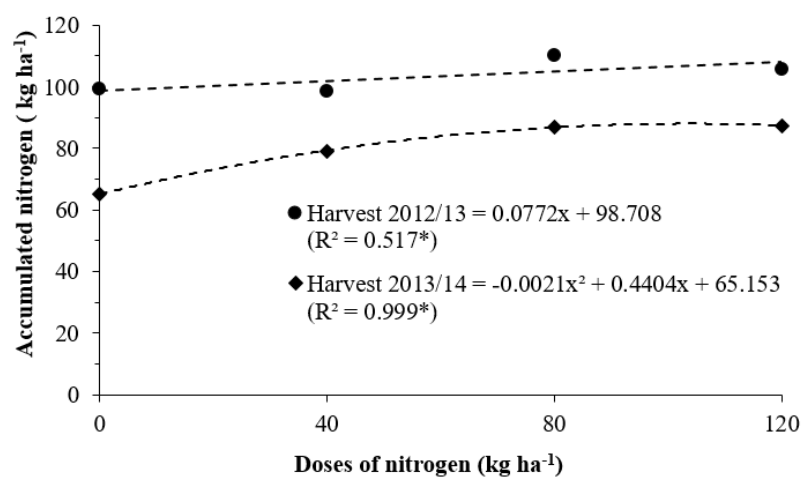

Fig 3. Accumulated nitrogen in the corn plants, in function of nitrogen doses in topdressing. Selvíria - MS, Brazil (Harvest 2012/13 and $2013 / 14)$. Test $\mathrm{F}:{ }^{*}$-significant at $5 \%$ probability.

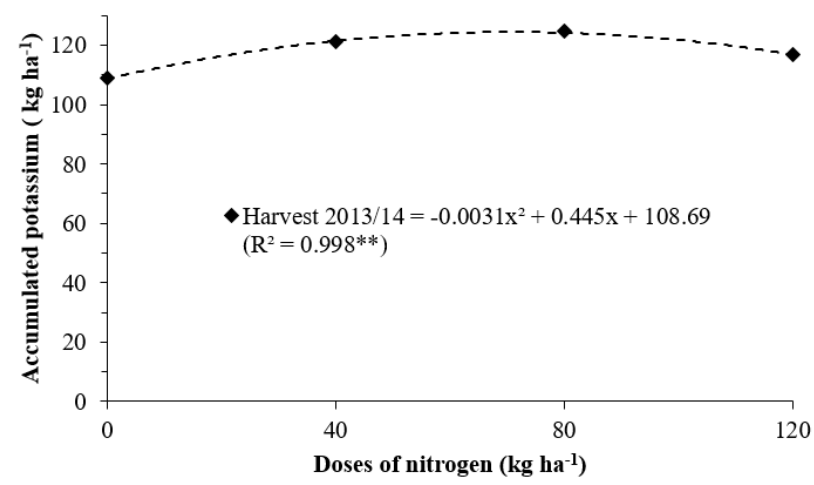

Fig 4. Accumulated potassium in the corn plants, in function of nitrogen doses in topdressing. Selvíria - MS, Brazil (Harvest 2013/14). Test F: ** - significant at $1 \%$ probability. 
second year, the treatments did not affect the accumulation of $P$. In relation to the $K$ accumulated in cover crops (Table 1 ) during both years of research, the highest concentration of this nutrient occurred in the millet + crotalaria treatment in relation to the pigeon pea treatment. This was similar to the data reported by Gitti et al. (2012). Differently from the results obtained in this study, Silva et al. (2010), studying nutrient accumulation in crotalaria, millet and millet + crotalaria intercropping, reported a higher amount of $\mathrm{K}$ for millet compared to other cover crops. This superiority was attributed to a higher accumulation of dry matter $(14,040 \mathrm{~kg}$ $\left.\mathrm{ha}^{-1}\right)$ and of $\mathrm{K}$ content in millet $\left(22.9 \mathrm{~g} \mathrm{~kg}^{-1}\right)$. Perin et al. (2010) did not report differences in the accumulated amount of $\mathrm{K}$ for crotalaria, millet, millet + crotalaria intercropping and spontaneous vegetation.

The amount of N, P and K accumulated by pigeon pea plants was low because of the time the pigeon pea took to develop and accumulate dry matter. As the flowering of crotalaria and millet occurred at 63 DAE during the first year and at $60 \mathrm{DAE}$ during the second year, we performed the management of both plants (including the pigeon pea treatment). According to Dalal (1980), Wijnberg and Whiteman (1985), pigeon pea accumulates most of the dry matter and nutrients between flowering and maturation. For this reason, the management should be performed at full flowering at the beginning of pod formation (Carvalho and Amabile, 2006).

\section{Initial population of plants, accumulation of dry matter and nutrients in corn plants}

Regarding the initial population of plants (IPP) (Table 2), pigeon pea allowed a larger initial population compared to the millet and millet + pigeon pea treatments. This probably occurred because millet has a high content of cellulose and hemicellulose, which are known as components of plant residues with lower degradation rate (Cobo et al., 2002; Jensen et al., 2005) compared to pigeon pea. Weiler (2012) reported a high content of cellulose and hemicellulose in millet ( 374 and $277 \mathrm{~g} \mathrm{~kg}^{-1}$ ) and a low content in legumes: dwarf pigeon pea has 370 and $147 \mathrm{~g} \mathrm{~kg}^{-1}$, respectively. High contents of cellulose and hemicellulose provided a great resistance to millet residues from cutting by harrow discs, interfering with seed distribution. In addition, pigeon pea also presented a low accumulated dry matter, providing a better straw cutting by harrow discs and a better distribution of corn seeds.

According to Silva et al. (2012), the highest values of penetration depth of seed drill discs were obtained for cover turnip rootlet followed by triticale, black oat, corn and sorghum. Such results can be explained by the low amount of dry matter of turnip rootlet. It facilitates the penetration of the discs into the soil. The low values obtained for sorghum cover are due to the difficulty of cutting straw, which is very fibrous and resistant. Santos et al. (2010) observed that high amounts of straw may affect the sowing operation by interfering with furrow depth, which may consequently affect crop germination.

Inoculation, cover crops and $\mathrm{N}$ doses applied in topdressing on corn did not influence the average accumulated shoot dry matter (SDM) during the first agricultural year. Bertin et al. (2005), evaluating pre-harvest cover crops using a no-tillage system, reported that the dry matter of accumulated corn did not present a significant difference in any of the treatments.

During the second year, SDM was high in crotalaria and millet + crotalaria, which presented the highest averages, differing only from the millet + pigeon pea treatment. Millet + crotalaria had the highest accumulation of $\mathrm{N}$ and $\mathrm{K}$, which reflected in a high dry matter per corn plant (Table 3 ). Crotalaria, even when presenting less nutrients than millet + crotalaria, was able to make the nutrients available more quickly due to its low $\mathrm{C} / \mathrm{N}$ ratio.

Corn SDM responded in a quadratic manner in function of increasing doses of $\mathrm{N}$ in topdressing (Fig 2). The highest accumulation of dry matter $\left(5,951 \mathrm{~kg} \mathrm{ha}^{-1}\right)$ occurred by applying the $\mathrm{N}$ dose of $85 \mathrm{~kg} \mathrm{ha}^{-1}$. Fernandes et al. (2005), studying corn genotypes and $\mathrm{N}$ doses, found that the maximum accumulation of dry matter, measured at flowering, occurred by using the estimated $N$ dose of $84 \mathrm{~kg}$ $\mathrm{ha}^{-1}$. Andrioli et al. (2008), studying plant covers and $\mathrm{N}$ doses in topdressing, observed a quadratic response in function of $\mathrm{N}$ doses for the Brachiaria brizantha + lab-lab, millet and crotalaria treatments, with a peak of $99 \mathrm{~kg} \mathrm{ha}^{-1}, 77 \mathrm{~kg} \mathrm{ha}^{-1}$ and $78 \mathrm{~kg} \mathrm{ha}^{-1}$, respectively. Carvalho et al. (2011), evaluating the performance of corn genotypes as for the efficiency of nitrogen fertilization, reported that most of them presented an increase in SDM when the dose was changed from 40 to $160 \mathrm{~kg} \mathrm{ha}^{-1}$ of $\mathrm{N}$ in topdressing. The amount of $\mathrm{N}$ accumulated per hectare in corn plants, during the first year, differed only regarding $\mathrm{N}$ doses in topdressing (Table 3). Based on the data shown in Fig 3, it can be observed that the $\mathrm{N}$ doses adjusted to a positive linear function, in which the increase in $\mathrm{N}$ doses in topdressing resulted in an increase in the amount of accumulated $\mathrm{N}$. This can be explained, according to Silva et al. (2009), because the mineral fertilizer provides most of the $\mathrm{N}$ accumulated in corn plants, followed by soil and green manures. The amount of $\mathrm{N}$ accumulated also increased linearly in response to the increasing doses of cover $\mathrm{N}$ in an experiment conducted by Kappes et al. (2013a). Gava et al. (2010) concluded that the increase in $\mathrm{N}$ fertilizer doses promoted an increase in $\mathrm{N}$ accumulation in corn plants.

During the second year, plant cover affected the $\mathrm{N}$ accumulated by corn plants (Table 3 ). The crotalaria treatment presented the greatest accumulation in relation to millet + pigeon pea treatment. The accumulation of $\mathrm{N}$ by corn plants is a result from the dry matter accumulation of corn plants and the $\mathrm{N}$ content of these plants. As the SDM (Table 2) showed a superiority in the crotalaria treatment compared to the millet + pigeon pea treatment and as the $\mathrm{N}$ content of the plants did not differ statistically, it can be stated that the highest accumulation of $\mathrm{N}$ by corn plants was a result from SDM. Majerowicz et al. (2002) reported that the accumulation of dry matter in the shoots of corn plants was affected by the application of $\mathrm{N}$. The authors explained that $\mathrm{N}$ deficiency strongly affects plant growth.

Table 3 also shows that the accumulated $\mathrm{N}$ responded to $\mathrm{N}$ doses. Fig 3 shows that, unlike the first year, the doses adjusted to a quadratic model regarding the $\mathrm{N}$ accumulated during the second year. The maximum accumulated, according to the equation, would be $88 \mathrm{~kg} \mathrm{ha}^{-1}$ of $\mathrm{N}$ using the dose $105 \mathrm{~kg} \mathrm{ha}^{-1}$. It is known that the efficiency of nitrogen fertilization rarely reaches $50 \%$. Therefore, in this analogy, part of the $\mathrm{N}$ accumulated by plants came from the fertilizer 
and the other part probably came from the organic matter in the soil.

Regarding accumulated $\mathrm{P}$ and $\mathrm{K}$ during the first year, there were no differences (Table 3 ). During the second year, the accumulated $\mathrm{P}$ and $\mathrm{K}$ (Table 3 ) responded similarly to plant covers. This is also a result of a high accumulation of dry matter by corn plants. The millet + crotalaria treatment excelled the millet + pigeon pea treatment. Kappes et al. (2013a) verified that the $\mathrm{N}, \mathrm{P}$ and $\mathrm{K}$ accumulated was higher in crotalaria and millet + crotalaria compared to millet. However, the authors attributed this effect to the accumulated dry matter, since the nutrient content in the whole plant was similar. Silva et al. (2006), studying the effects of cover crops on the $\mathrm{N}$ accumulated by corn plants, reported a high amount of $\mathrm{N}$ accumulated in the crotalaria treatment in relation to the millet treatment. The authors stated that it was proportional to the production of dry matter: crotalaria provided a greater accumulated dry matter production to corn compared to millet.

During the second year, the accumulated $\mathrm{K}$ (Table 3 ) responded according to $\mathrm{N}$ doses. Fig 4 shows that the data adjusted to a quadratic model. The $\mathrm{N}$ dose $72 \mathrm{~kg} \mathrm{ha}^{-1}$ was highlighted, resulting in a high accumulation of K. Again, this reinforces the link between corn SDM (Fig 2) and nutrient accumulation. In this case, SDM also followed a quadratic tendency regarding $\mathrm{N}$ doses. Therefore, it can be inferred that, up to a certain extent, there was not necessarily an induction of a greater accumulation of $\mathrm{K}$ by corn plants in function of $\mathrm{N}$ doses. What happened, in fact, was a result from the great accumulation of dry matter by the plant. Malavolta et al. (1997) mentioned the most common effects exerted by these elements and demonstrated that the addition of $\mathrm{N}$ promotes a decrease of $\mathrm{K}$ in leaves. Viana and Kiehl (2010) reported that the accumulation of potassium in wheat shoots varied only according to the addition of potassium. There was no interaction with nitrogen supply.

\section{Materials and Methods}

\section{Description of the area: location, climate and soil}

We conducted this study during two agricultural years (2012/13 and 2013/14) at an experimental area of the Faculty of Engineering (UNESP), Ilha Solteira campus, located in the municipality of Selvíria, MS, at approximately 51⒉' $W$ and 20.22' S. The altitude was 335 meters.

The climate of the region, according to the Köppen classification, is Aw: tropical humid, rainy in the summer and dry in the winter. According to Portugal et al. (2015), the average annual rainfall is $1,330 \mathrm{~mm}$, with an average minimum temperature of $19^{\circ} \mathrm{C}$ and an average maximum temperature of $31^{\circ} \mathrm{C}$. The values for rainfalls, minimum and maximum temperatures during the conduction of the experiment are shown in Fig 1 ( $A$ and $B$ ).

The soil of the experimental area is a typical clayey dystrophic Red Latosol (Santos et al. 2013), whose chemical analysis is shown in Table 4.

The experimental area has been cultivated using the notillage system since the $1997 / 98$ agricultural year. In the summers of $2009 / 10,2010 / 11$ and $2011 / 12$, the area was sown with rice. In the winter of those same years, the area was sown with wheat in the first two years and beans in the last year. During 2012/13 and 2013/14, the area was cultivated with corn in the summer and beans in the winter. After the winter harvest, the area was cultivated with millet, crotalaria, pigeon pea, millet + crotalaria, millet + pigeon pea and fallow (spontaneous plants). Each use of vegetation cover was repeated during the last five years in the same places of cultivation.

\section{Experimental design and treatments}

The experimental design was randomized blocks in a $6 \times 4 \times 2$ factorial design totaling 48 treatments consisting of six cover crops [millet (Pennisetum americanum), crotalaria (Crotalaria juncea), pigeon pea (Cajanus cajan), millet + crotalaria, millet + pigeon pea and fallow]. We applied four doses of cover $N\left(0,40,80\right.$ and $\left.120 \mathrm{~kg} \mathrm{ha}^{-1}\right)$ with and without inoculation via seeds using Azospirillum brasilense. The plots consisted of 7 planting rows $6.0 \mathrm{~m}$ long and $0.45 \mathrm{~m}$ apart.

\section{Plant materials}

Crotalaria juncea L. is a fabacea, native from the India and Tropical Asia, with great cultivation potential in the Cerrado region. It presents fast growth, promoting fast soil cover, with potential of dry mass production from $4 \mathrm{t} \mathrm{ha}^{-1}$ to $15 \mathrm{t}$ $\mathrm{ha}^{-1}$ and in regions with rainfall of 200 to $400 \mathrm{~mm}$. It obtains excellent $\mathrm{N}_{2}$ fixation capacity, between $150 \mathrm{~kg} \mathrm{ha}^{-1}$ and 165 $\mathrm{kg} \mathrm{ha}^{-1}$ per year (Wutke et al., 2014).

The pigeon pea (Cajanus cajan L.), also from India and tropical Asia, has great potential for cultivation in the Cerrado region. It has slow initial growth, however, it can produce dry mass of 5 to $18 \mathrm{tha}^{-1}$ in regions with 200 to 400 $\mathrm{mm}$ of rainfall. It provides beneficial effects for the fixation of $\mathrm{N} 2$, being able to fix from 41 to $280 \mathrm{~kg}$ of $\mathrm{N} \mathrm{ha}^{-1}$ per year and, due to the root exudations, like the pisidic acids, is responsible by the solubilization and availability of $P$ combined with iron (Wutke et al., 2014).

Millet (Pennisetum glaucum L.) forage specie of tropical climate, indicated for the Cerrado region; shows fast growth; vigorous root system; high tillering and nutrient cycling potential. It is a plant resistant to drought, therefore, requires approximately $30 \mathrm{~mm}$ of precipitation for germination; produces on average $10 \mathrm{t} \mathrm{ha}^{-1}$ dry mass (Wutke et al., 2014).

Regarding the fallow, during the first year, there was a predominance of Urochloa ruziziensis; in the second year, the following species of plants appeared: Bidens pilosa, Acanthospermum hispidum, Commelina benghalensis, Phaseolusvulgaris, Euphorbia heterophylla, Sorghum bicolor, Eleusine indica and Urochloa ruziziensis.

In the first and second year in the sowing of the corn were use the simple hybrids DKB 390 VT PRO and 2B710 PW, respectively. These hybrids have early cycle, grains of yellow/orange coloring and are indicated for the production of grains.

\section{Installation and conducting of field experiment}

The sowing of the cover crops was made on 09/05/2012 and $09 / 09 / 2013$. We used a tractor seeder to mark the lines, with a spacing of $0.45 \mathrm{~m}$ between rows. The sowing of cover crops was performed manually using planting forks without fertilization. We used an average of $60 \mathrm{~kg} \mathrm{ha}^{-1}$ of pigeon pea, $25 \mathrm{~kg} \mathrm{ha}^{-1}$ of crotalaria and $15 \mathrm{~kg} \mathrm{ha}^{-1}$ of millet seeds. In the 
treatments containing vegetal cover intercropping, $50 \%$ of seeds of each species were used. Water supply, when necessary, was performed by a fixed sprinkler irrigation system with a three-day irrigation frequency.

At the flowering of millet and crotalaria, 63 days after emergence (DAE) (11/12/2012) and 58 DAE (11/13/2013), the chemical management of all vegetation cover was performed by applying the herbicides 2,4 D and glyphosate at doses of 1,209 and 1,440 $\mathrm{g} \mathrm{ha}{ }^{-1}$ of a.i., respectively, for desiccation of the plants existing in the experimental area. After nine days of chemical management, the area was managed with a Triton mechanical disintegrator to facilitate the sowing of the crop, demarcation of experimental plots, and to allow the degradation of a large part of the herbicide used for desiccation, exempting corn from any toxic effects. The liming of the area, during the first year, was performed by using $1.64 \mathrm{t} \mathrm{ha}^{-1}$ of lime with a 73\% PRNT. During the second year, it was performed using $1.5 \mathrm{t} \mathrm{ha}^{-1}$ of lime with an $80.3 \%$ PRNT.

At 2 and 3 days after the management of the cover crops with Triton ${ }^{\circledR}$ in the first and second year respectively, the corn sowing was performed on the straw of these cover crops, according to each treatment, aiming to evaluate their effects on the corn nutrition.

The mechanical sowing of corn was performed on $11 / 23 / 2012$ and $11 / 25 / 2013$ using the simple hybrids DKB 390 VT PRO and 2B710 PW, respectively.

The seeds were treated during both years with imidacloprid and thiodicarb at doses of 50 and $150 \mathrm{~g}$ a.i., respectively, for 60,000 seeds to avoid the initial attack of possible pest insects. After seed treatment, the inoculation was carried out in a shaded environment shortly before sowing using the marterfix gramíneas ${ }^{\circledR}$ inoculant of the Stoller $^{\circledR}$ company, that contains Azospirillum brasilense strains $A b-V_{5}$ and $A b-$ $V_{6}$. The inoculant used had $2 \times 10^{8}$ viable cells per gram of commercial product. The dose of $200 \mathrm{~g}$ of turf inoculant was applied during the first year and $200 \mathrm{~mL}$ of liquid inoculant for $25 \mathrm{~kg}$ of seeds was applied during the second year. Three seeds per meter of furrow were distributed at a spacing of $0.45 \mathrm{~m}$ between the lines aiming to obtain $60-65$ thousand plants $h a^{-1}$.

The basic mineral fertilization in the sowing furrows of the corn was calculated according to the soil chemical characteristics and taking into account the recommendations made by Cantarella and Furlani (1996). During the first year, we used $24 \mathrm{~kg} \mathrm{ha}^{-1}$ of $\mathrm{N}, 84 \mathrm{~kg} \mathrm{ha}^{-1}$ of $\mathrm{P}_{2} \mathrm{O}_{5}$ and $48 \mathrm{~kg} \mathrm{ha}^{-1}$ of $\mathrm{K}_{2} \mathrm{O}$; in the second year, $26 \mathrm{~kg} \mathrm{ha}^{-1}$ of $\mathrm{N}, 92 \mathrm{~kg} \mathrm{ha}^{-1}$ of $\mathrm{P}_{2} \mathrm{O}_{5}$ and $52 \mathrm{~kg} \mathrm{ha}^{-1}$ of $\mathrm{K}_{2} \mathrm{O}$.

The nitrogen fertilization in topdressing (nitrogen doses) was performed at the complete formation of the $5^{\text {th }}$ leaf, on $12 / 17 / 2012$, at 18 DAE in the first year. In the second year, the nitrogen fertilization in topdressing was performed on $12 / 16 / 2013$ at 17 DAE. The N source was urea distributed on the soil surface next to the corn lines. After, the area was irrigated to minimize losses by ammonia volatilization.

In order to keep the crop free from competition with invasive plants during both years, the herbicides atrazine and tembotrione were applied at post-emergence at rates of 1,000 and $100 \mathrm{~g} \mathrm{ha}^{-1}$ of i.a., respectively, in the form of a tank mix.

The female flowering of the crop, in the first year, occurred on $01 / 16 / 2013$ at 48 DAE; in the second year, on $01 / 17 / 2014$ at $49 \mathrm{DAE}$.

\section{Variables analyzed in cover crops}

After the management of the cover crops with Triton $^{\circledR}$, a sample of the resulting straw in each plot was collected and the nitrogen, phosphorus and potassium accumulated in these cover crops were evaluated.

\section{Variables analyzed in corn plants}

In the corn plants were evaluated: initial population at 10 DAE, accumulated dry matter at female flowering, and accumulated amount of nitrogen, phosphorus and potassium at female flowering.

\section{Statistical analysis}

The results were submitted to the $F$ test of analysis of variance. When a significant result was verified by the $F$ test ( $p \leq 0.01$ and $\leq 0.05)$, a Tukey test $(p \leq 0.05)$ was performed to compare averages of plant covers and seed inoculation, and a polynomial regression was performed for nitrogen doses.

\section{Conclusion}

Millet + crotalaria intercropping allows high accumulated amounts of $\mathrm{N}$ and $\mathrm{K}$ and results in a high accumulation of dry matter and nutrients by corn plants sown in succession. The cover nitrogen fertilization provided an increase in the dry matter accumulated by corn plants of up to $85 \mathrm{~kg} \mathrm{ha}^{-1}$. Inoculation via seeds using Azospirillum brasilense did not increase the accumulation of dry matter and nutrients by corn plants.

\section{Acknowledgements}

The authors would like to thank the Foundation Research Support of the State of São Paulo (FAPESP) for the scholarship awarded to the first author (Process FAPESP $n$. 2012/22501-9) and for funding current research.

\section{References}

Amado TJC, Mielniczuk J, Aita C (2002) Recomendação de adubação nitrogenada para o milho no RS e SC adaptada ao uso de culturas de cobertura do solo, sob sistema de plantio direto. Rev Bras Cienc Solo. 26 (2): 241-248.

Andrioli I, Beutler NA, Centurion JF, Andrioli FF, Countinho ELM (2008) Produção de milho em plantio direto com adubação nitrogenada e cobertura do solo na pré-safra. Rev Bras Cienc Solo. 32 (4): 1691-1698.

Bashan Y, Bashan LE (2005) Plant growth-promoting. In: Hillel D (ed) Encyclopedia of soil in the environment. Elsevier, Oxford. p.103-115.

Bertin G, Andrioli I, Centurion JF (2005) Plantas de cobertura em pré-safra ao milho em plantio direto. Acta Scie-Agron. 27 (3): 379-386

Broch DL, Ranno SK (2008) Fertilidade do solo, adubação e nutrição da cultura do milho. In: Broch DL (ed). Tecnologia de produção: soja milho. 2008/2009. n.5. Fundação MS, Maracaju. p.133-141.

Buzinaro TN, Barbosa JC, Nahas E (2009) Atividade microbiana do solo em pomar de laranja em resposta ao cultivo de adubos verdes. Rev Bras Frutic. 31 (2): 408-415. 
Cantarella H, Furlani PR (1996) Arroz de sequeiro. In: Raij B van, Cantarella H, Quaggio JA, Furlani AMC (eds) Recomendações de adubação e calagem para o Estado de São Paulo, 2nd edn. Instituto agronômico e Fundação IAC , Campinas. 285 p.

Carvalho AM, Amabile RF (2006) Plantas condicionadoras de solo: interações edafoclimáticas, uso e manejo. In: Carvalho AM, Amabile RF (eds) Cerrado: adubação verde. Embrapa, Brasília. p.143-170.

Carvalho RP, Von Pinho RG, Davide LMC (2011) Desempenho de cultivares de milho quanto à eficiência de utilização de nitrogênio. Rev Bras Milho Sorgo. 10 (2): 108-120.

Cobo JG, Barrios E, Kass DCL, Thomas RJ (2002) Decomposition and nutrient release by green manures in tropical hillside agroecosystem. Plant Soil. 240: 331-342.

Coelho AM, França GD (1995) Seja o Doutor do seu Milho. Arquivo do agrônomo $n^{\circ} 2$. Potafos, Piracicaba.

Dalal RC (1980) Nutrient element concentration and dry matter production by filed grow pigeon pea (Cajanus cajan (L.) Millsp.) Trop Agr. 57 (2): 107-112.

Fancelli AL (2015) Ecofisiologia, fenologia e implicações básicas de manejo. In: Borém A, Galvão JCC, Pimentel MA (ed) Milho: do plantio a colheita. Ed. UFV, Viçosa. cap. 3, p. 50-76.

Fernandes FCS, Buzetti S, Arf O, Andrade JAC (2005) Doses, eficiência e uso de nitrogênio por seis cultivares de milho. Rev Bras Milho Sorgo. 4(2): 195-204.

Ferreira LE, Souza EP, Chaves AF (2012) Adubação verde e seu efeito sobre os atributos do solo. Rev Verde. 7 (1): 3338.

Fornasieri Filho D (2007) Manual da cultura do milho. Funep, Jaboticabal. $576 \mathrm{p}$.

Gava GJC, Oliveira MW, Silva MA, Jerônimo EM, Cruz JCS, Trivelin PCO (2010) Produção de fitomassa e acúmulo de nitrogênio em milho cultivado com diferentes doses de 15N-uréia. Semin-Cienc Agrar. 31(4): 851-862.

Gitti DC, Arf O, Portugal JR, Corsini DCDC, Rodrigues RAF, Kaneko FH (2012) Coberturas vegetais, doses de nitrogênio e inoculação de sementes com Azospirillum brasilense em arroz de terras altas no sistema plantio direto. Bragantia. 71(4): 509-517.

Hungria M, Campo RJ, Souza EM, Pedrosa FO (2010) Inoculation with selected strains of Azospirillum brasilense and $A$. lipoferum improves yields of maize and wheat in Brazil. Plant Soil. 331:413-425.

Jensen LS, Salo T, Palmason F, Breland TA, Henriksen TM, Stenberg B, Pedersen A, Lundström C, Esala M (2005) Influence of biochemical quality on $\mathrm{C}$ and $\mathrm{N}$ mineralization from a broad variety of plant materials in soil. Plant Soil. 273: 307-326.

Kappes C (2011) Utilizações e benefícios da crotalária na agricultura. Panorama Rural. 147: 16-17.

Kappes C, Arf O, Andrade JAC (2013a) Coberturas vegetais, manejo do solo, doses de nitrogênio e seus efeitos na nutrição mineral e nos atributos agronômicos do milho. Rev Bras Cienc Solo. 37 (5): 1322-1333.

Kappes C, Arf O, Andrade JAC (2013b) Produtividade do milho em condições de diferentes manejos do solo e de doses de nitrogênio. Rev Bras Cienc Solo. 37 (5): 13101321.

Majerowicz N, Pereira JMS, Medici LO, Bison O, Pereira MB, Santos Júnior UM (2002) Estudo da eficiência de uso do nitrogênio em variedades locais e melhoradas de milho. Rev Bras Bot, 25 (2): 129-136.

Malavolta E, Vitti GC, Oliveira AS (1997) Avaliação do estado nutricional das plantas: princípios e aplicações, 2nd edn. Potafos, Piracicaba. $319 \mathrm{p}$.

Marini D, Guimarães VF, Dartora J, Lana MC, Pinto Júnior AS (2015) Growth and yield of corn hybrids in response to association with Azospirillum brasilense and nitrogen fertilization. Rev Cer. 62 (1):117-123.

Moreira FMS, Silva K, Nóbrega RSA, Carvalho F (2010) Bactérias diazotróficas associativas: diversidade, ecologia e potencial de aplicações. Com Sci. 1 (2): 74-99.

Nunes EN, Montenegro INA, Nascimento DAM, Silva DA, Nascimento R (2013). Análise e crescimento e assimilação de nitrogênio em plantas de milho (Zea mays L.). Rev Ver. 28 (4):72-76.

Ohland RAA, Souza LCF, Hernani LC, Marchetti ME, Gonçalves MC (2005) Culturas de cobertura do solo e adubação nitrogenada no milho em plantio direto. Ciênc Agrotec. 29 (3): 538-544.

Perin A, Santos RHS, Urquiaga S, Guerra JGM, Cecon PR (2004) Produção de fitomassa, acúmulo de nutrientes e fixação biológica de nitrogênio por adubos verdes em cultivo isolado e consorciado. Pesqui Agropecu Bras. 39 (1): 35-40.

Portugal JR, Peres AR, Rodrigues RAF (2015) Aspectos climáticos no feijoeiro. In: Arf O, Lemos LB, Soratto RP, Ferrari S (ed) Aspectos gerais da cultura do feijão Phaseolus vulgaris L. FEPAF, Botucatu. cap. 4, p.65-75.

Rambo L, Silva PRF, Argenta G, Sangoi L (2004) Parâmetros de planta para aprimorar o manejo da adubação nitrogenada de cobertura em milho. Cienc Rural. 34 (5): 1637-1645.

Repke RA, Cruz SJS, Silva CJ, Figueiredo PG, Bicudo SJ (2013) Eficiência da Azospirillum brasilense combinada com doses de nitrogênio no desenvolvimento de plantas de milho. Rev Bras Milho Sorgo. 12 (3): 214-226.

Roberto VMO, Silva CD, Lobato PN (2010) Resposta da cultura do milho a aplicação de diferentes doses de inoculante (Azospirillum brasilense) via semente. Paper presented at the 28th Congresso nacional de milho e sorgo, Embrapa, Goiânia, 29-02 September 2010.

Santos AJM, Gamero CA, Backes C, Salomão LC, Bicudo SJ (2010) Desempenho de discos de corte de semeadoraadubadora em diferentes quantidades de cobertura vegetal. Energ Agr. 25 (4): 17-30.

Santos HG, Jacomine PKT, Oliveira VA, Lumbreras JF, Coelho MR, Almeida JA, Cunha TJF, Oliveira JB (2013) Sistema brasileiro de classificação de solos. 3rd edn. Embrapa, Brasília. 353 p.

Silva EC, Mukaoka T, Guimarães GL, Buzetti S (2006) Acúmulo de nutrientes em plantas de cobertura e no milho cultivado em sucessão sob diferentes doses de nitrogênio em plantio direto. Rev Bras Milho Sorgo. 5 (2): 202-217.

Silva EC, Muraoka T, Villanueva FCA, Espinal FSC (2009) Aproveitamento de nitrogênio pelo milho, em razão da adubação verde, nitrogenada e fosfatada. Pesqui Agropecu Bras. 44 (2) 118-127.

Silva FC, Silva, MM, Libadi PL (2013) Aplicação de nitrogênio no cultivo de milho, sob sistema plantio direto: efeitos na qualidade física do solo e características agronômicas. Semin-Cienc Agrar. 34 (6): 3513-3528. 
Silva PRA, Benez H, Jasper SP, Seki AS, Masiero FC, Riquetti NB (2012) Semeadora-adubadora: Mecanismos de corte de palha e cargas verticais aplicadas. Rev Bras Eng Agr Amb. 16 (12): 1367-1373.

Teixeira CM, Carvalho GJ, Andrade MJB, Silva CA, Pereira JM (2009) Decomposição e liberação de nutrientes das palhadas de milheto e milheto + crotalária no plantio direto do feijoeiro. Acta Scie-Agron. 31 (4): 647-653.

Torres JLR, Pereira MG, Andrioli I, Polidoro JC, Fabian AJ (2005) Decomposição e liberação de nitrogênio de resíduos culturais de plantas de cobertura em um solo de cerrado. Rev Bras Cienc Solo. 29 (4): 609-618.

Torres JLR, Pereira MG, Fabian AJ (2008) Produção de fitomassa por plantas de cobertura e mineralização de seus resíduos em plantio direto. Pesqui Agropecu Bras. 43 (3): 421-428.

Viana EM, Kiehl JC (2010) Doses de nitrogênio e potássio no crescimento do trigo. Bragantia. 69 (4): 975-982.
Von Pinho RG, Borges ID, Pereira JLAR, Reis MCD (2009) Marcha de absorção de macronutrientes e acúmulo de matéria seca em milho. Rev Bras Milho Sorgo. 8 (2): 157173.

Weiler DA (2012) Decomposição de resíduos culturais de plantas de cobertura de solo e emissões de óxido nitroso. Dissertação (Mestrado em Agronomia - Ciência do Solo) Centro de Ciências Rurais, Universidade Federal de Santa Maria, Santa Maria.

Wijnberg C, Whiteman PC (1985) Effects of stocking rate of goats and stage of crop growth when grazed on grain yield and goat production from pigeon pea (Cajanus cajan). Aust J Exp Agr. 25 (4): 796-805.

Wutke EB, Calegari A, Wildner LP (2014) Espécies de adubos verdes e plantas de cobertura e recomendações para seu uso. In: Lima Filho OFL, Ambrosano EJ, Rossi F, Carlos JAD (ed) Adubação verde e plantas de cobertura no Brasil: fundamentos e práticas. Embrapa, Brasília. p. 59-168. 